\title{
Muscle Moment and Angle of Hip, Knee and Ankle Joints in a Seven- Link Model of Backpack Sprayer Operator
}

\author{
Sedigheh Karimi Avargani ${ }^{1}$, Ali Maleki ${ }^{2 *}$, Shahin Besharati ${ }^{3}$, Reza Ebrahimi ${ }^{4}$
}

1. MSc Student, Department of Mechanical Engineering of Biosystems, Faculty of Agriculture, Shahrekord University, Shahrekord, Iran

2. Associate Professor, Department of Mechanical Engineering of Biosystems, Faculty of Agriculture, Shahrekord University, Shahrekord, Iran

3. Lecture, Department of Mechanical Engineering of Biosystems, Faculty of Agriculture, Shahrekord University, Shahrekord, Iran

4. Assistant Professor, Department of Mechanical Engineering, Faculty of Engineering, Yasouj University, Yasouj, Iran

\begin{tabular}{|c|c|}
\hline Article Info & ABSTRACT \\
\hline $\begin{array}{l}\text { Received: } 2020 / 02 / 13 ; \\
\text { Accepted: } 2020 / 05 / 29 ; \\
\text { ePublished: } 2020 / 09 / 5 \\
\text { doi } \frac{10.30699 / \text { iergon.8.3.36 }}{\text { Use your device to scan }} \\
\text { and read the article online } \\
\text { Corresponding Author } \\
\text { Ali Maleki } \\
\text { Associate Professor, } \\
\text { Department of Mechanical } \\
\text { Engineering of Biosystems, } \\
\text { Faculty of Agriculture, } \\
\text { Shahrekord University, } \\
\text { Shahrekord, Iran Email: }\end{array}$ & $\begin{array}{l}\text { Background and Objectives: Carrying of backpack sprayers is an inevitable part } \\
\text { of agricultural operations that increases the risk of injury along with undesirable } \\
\text { changes in walking mechanics. The purpose of this study is to formulate the muscle } \\
\text { moment changes in the hip, knee and ankle for the backpack sprayer operator body. } \\
\text { Methods: In this study, a seven-link sprayer operator model is designed and the } \\
\text { moment changes in the hip, knee and ankle joints are evaluated. Data are obtained } \\
\text { using Plot-digitizer software. Excel software is used to fit the third degree curve on } \\
\text { the data. } \\
\text { Results: In the hip joint, the moment is reduced by changing the angle from zero } \\
\text { to } 15^{\circ} \text {. At the end of the swing phase, the moment applied to the hip joint increases } \\
\text { with increasing the angle up to } 30^{\circ} \text {. In the beginning of the swing phase, the knee } \\
\text { joint starts to open at }-55^{\circ} \text {. At the end of the swing phase, the knee joint releases up } \\
\text { to }-5{ }^{\circ} \text { and the moment applied to the knee joint increases slowly. The moment } \\
\text { applied to the ankle joint increases by changing the ankle angle from - } 7.5^{\circ} \text { to } 7.5^{\circ} \text {. } \\
\text { Conclusion: According to the results of this study, amount of moment changes } \\
\text { of hip, knee and ankle joint affect the force applied to the backpack sprayer operator } \\
\text { body. With the knowledge of the moment changes of joints, practical solutions can } \\
\text { be provided to reduce amount of damage to these joints. }\end{array}$ \\
\hline
\end{tabular}

Keywords: Muscle moment, Body model, Seven-link model, Backpack sprayer maleki@sku.ac.ir

Copyright $($ C 2020, This is an original open-access article distributed under the terms of the Creative Commons Attribution-noncommercial 4.0 International License which permits copy and redistribute of the material just in noncommercial usages with proper citation.

\section{How to Cite This Article:}

Karimi Avargani S, Maleki A, Besharati S, Ebrahimi R. Muscle Moment and Angle of Hip, Knee and Ankle Joints in a Seven- Link Model of Backpack Sprayer Operator. Iran J Ergon. 2020; 8 (3) :36-47 


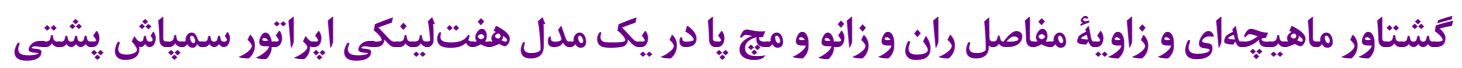

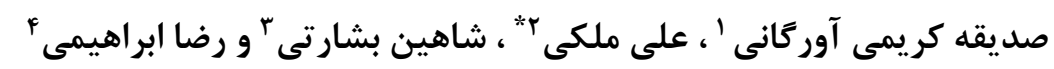

ا ا. دانشجوى كارشناسى ارشد، كروه مهندسى مكانيك بيوسيستم، دانشكدة كشاورزى، دانشكاه شهركرد، شهركرد، ايران

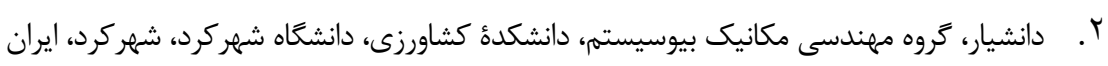

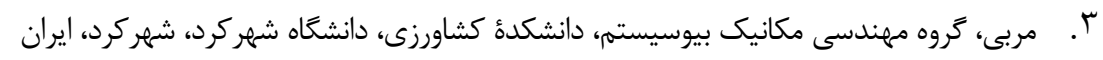

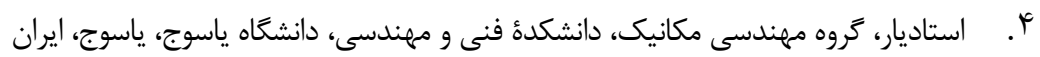

\begin{tabular}{|c|c|}
\hline خلاصه & اطلاعات مقاله \\
\hline 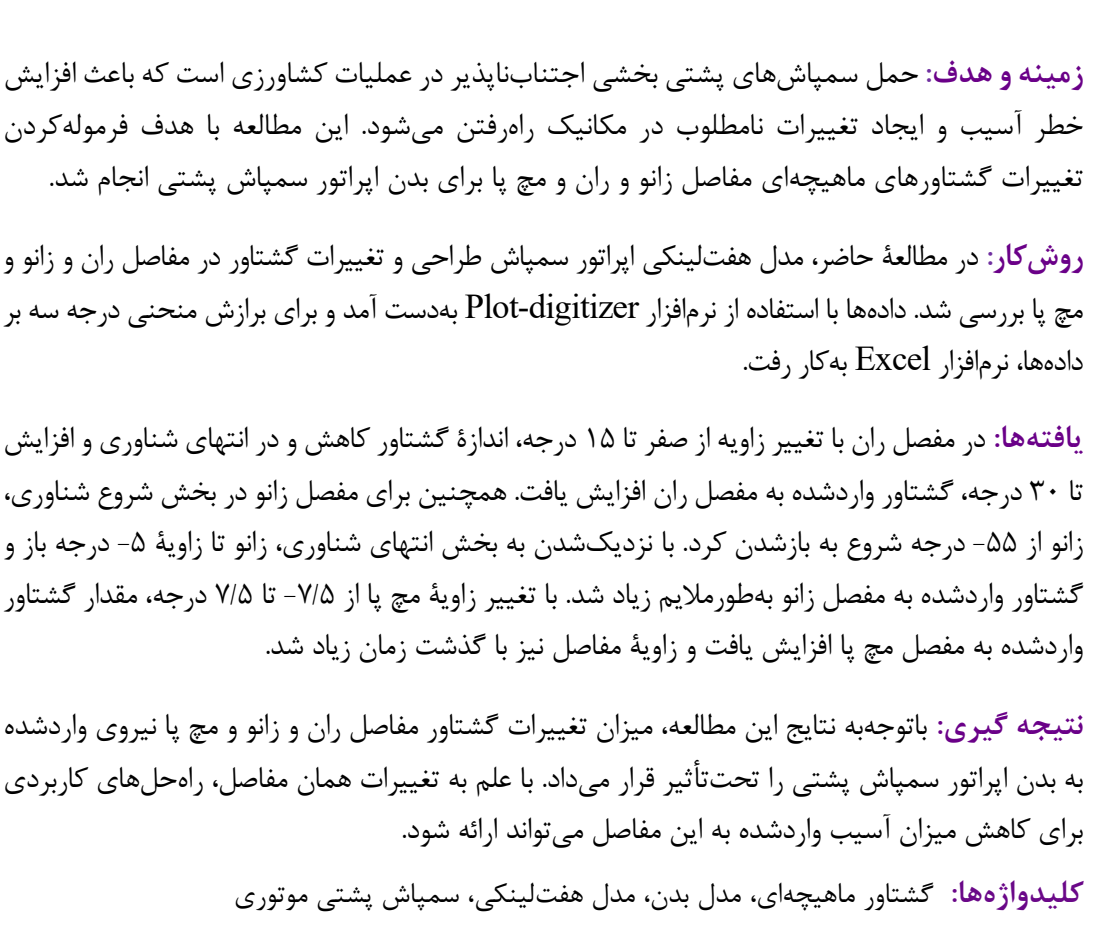 & 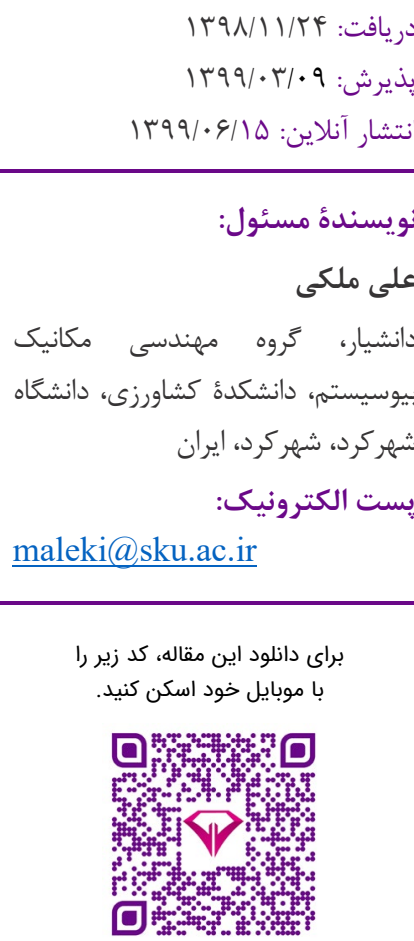 \\
\hline
\end{tabular}

مقدمه

اندام تحتانى و عضلات خموراستكننده اين مفاصل و حسكرهايى است كه در داخل اين مفاصل و اطراف آنها قرار دارند [هـ]. هنگًام حمل بار در كشاورزى نيز نيروهاى زيادى بر مفاصل مختلف بدن وارد

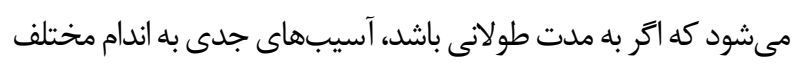

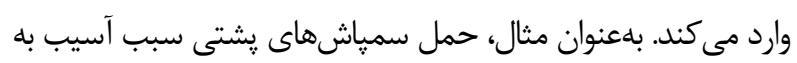

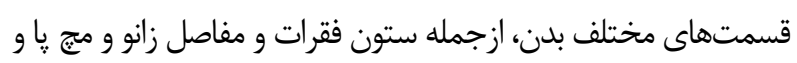

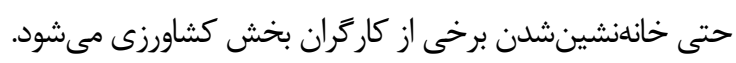

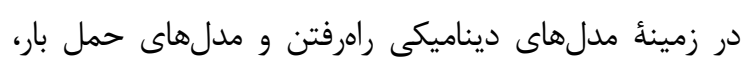
بررسىهاى متعددى انجام شده است. اين مطالعات طيف وسيعى از
مطالعهُ جرخهُ راهرفتن موضوعى است كه در رشتههاى متفاوت

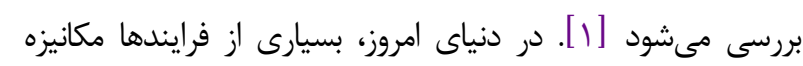

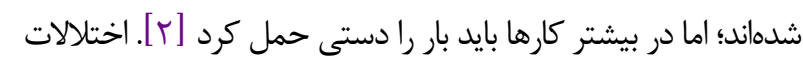
اسكلتىعضلانى يكى از آسيبهاى محيط كارى است كه بر سلامت جسمى كاركنان تأثير مى گذارد [ب]. شيوع دردهاى مفصلى إسى و اسكلتى عضلانى در مشاغلى بيشتر است كه بار فيزيكى زياد، رفتارهاى استاتيكى طولانى مدت، حركات تكرارى و حملونقل دستى دارند [c]. بسيارى از فرايندهاى پايدارى انسان در زمان ايستادن (يايدارى استاتيكى) و در زمان راهرفتن (يايدارى ديناميكى) به كمك مفاصل 
جرم ساق پا و ران در نظر گرفته شده است. براى بايدارى از

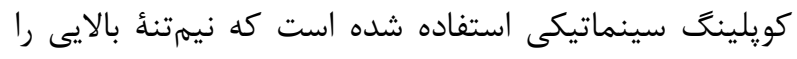

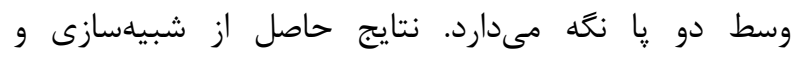

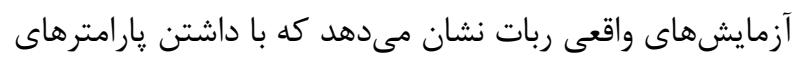
فيزيكى ثابت در طول راهرفتن و انطباق قوزكى يا، ربات مى دوات داند

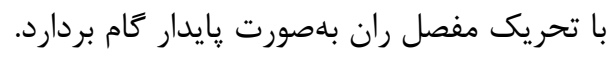

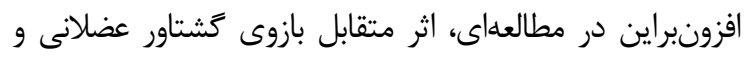

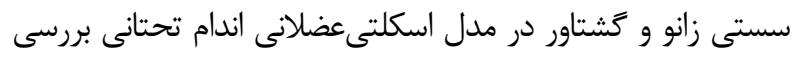

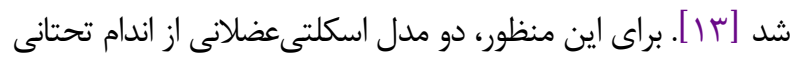

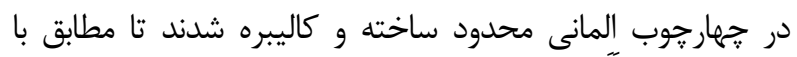

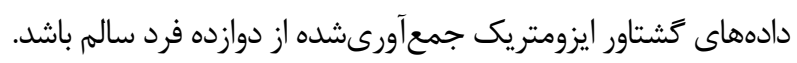

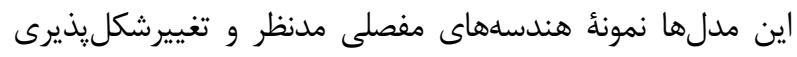

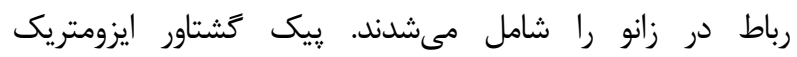

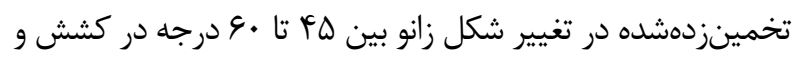

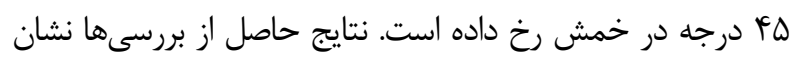

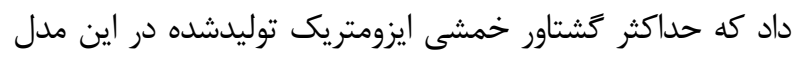

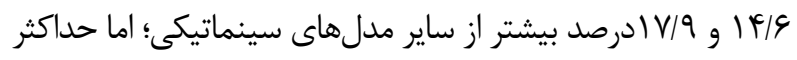

كشتاور كششى ايزومتريك توليدشده مدل ها مشابه بود. در يزوهشى ديكر، الكوهاى گَثتاور و انررى مفصل در راهرفتن

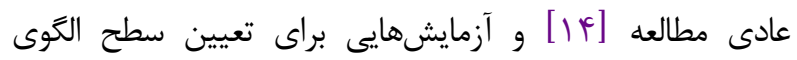

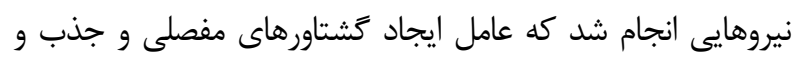

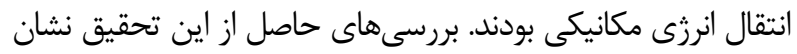

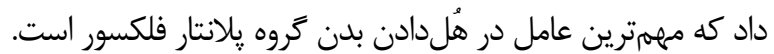

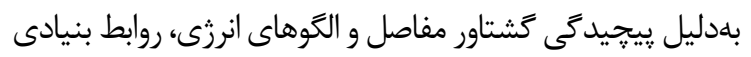

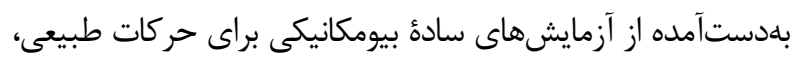

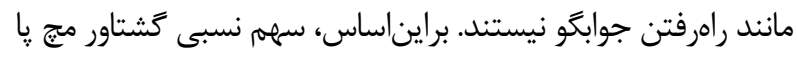

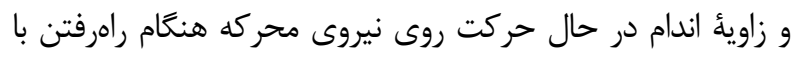

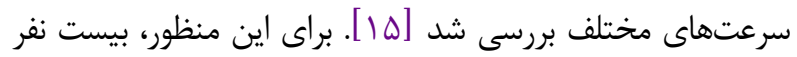

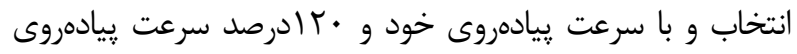
خود روى تردميل راه رفتند. اطلاعات سينماتيكى با استفاده از

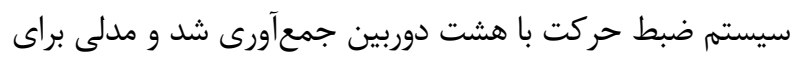

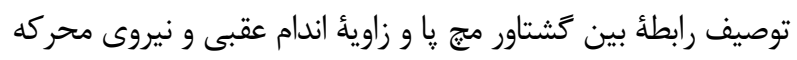

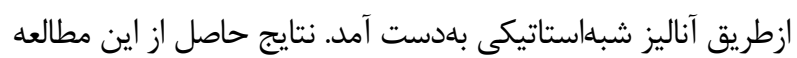

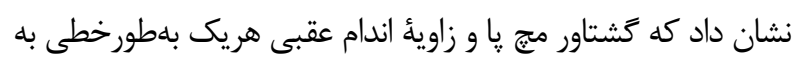
نيروى محركه كمك مى كنند. تغيير زاويئ اندام عقبى تقريباً دوبرابر

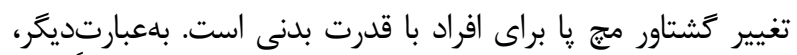

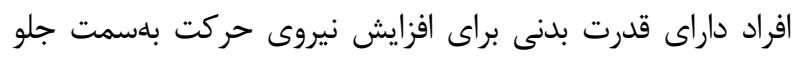

مدلها با درجات يِيحيدگى متفاوتى را شامل مىشوند. مدلها با

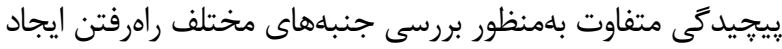

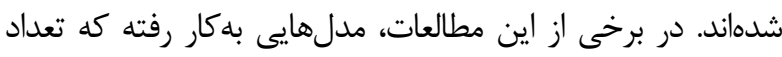

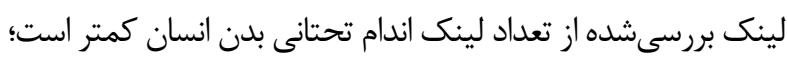

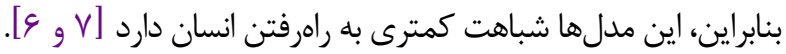
در يكى از مدلهاى ارائهشده براى ربات ينجلينكى، اثر عناصر

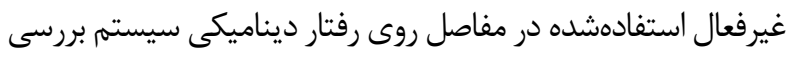

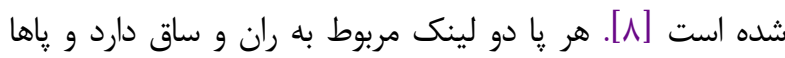

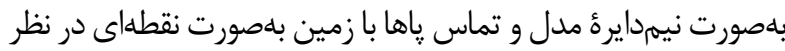

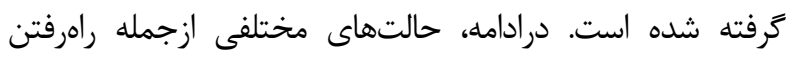

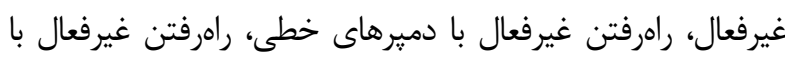

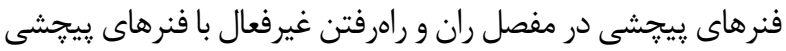

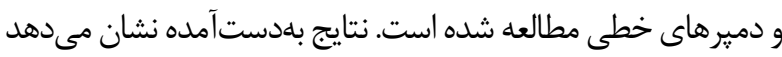

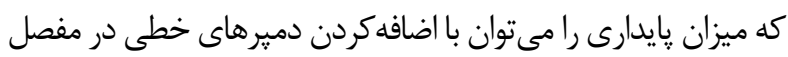

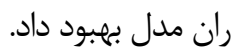
مدلى محاسباتى نيز براى تجزيهوتحليل ديناميك راهرفتن انسان

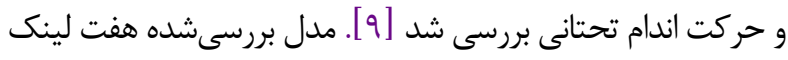

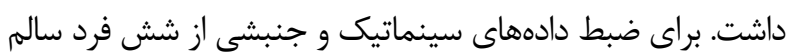

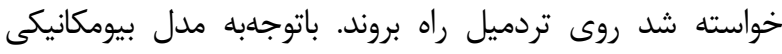

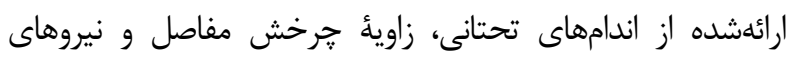

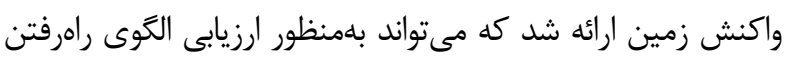

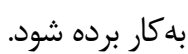
مطالعُ ديخرى بهمنظور شبيهسازى راهرفتن انسان انجام شد كه

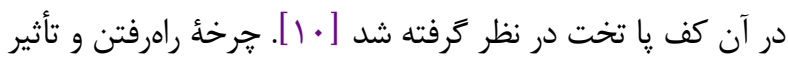

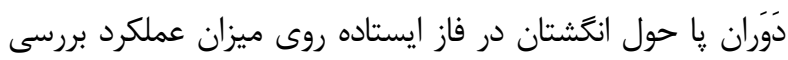

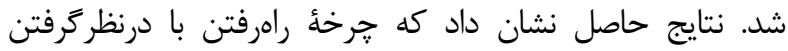
קرخش پا حول انگشتان عملكرد بهترى دارد.

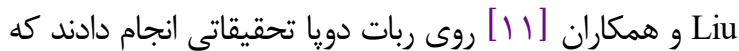

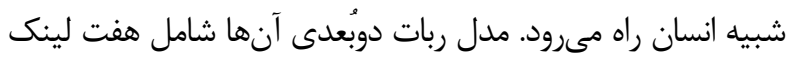

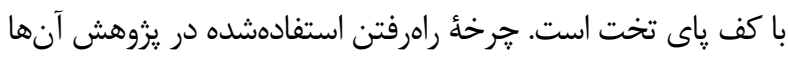

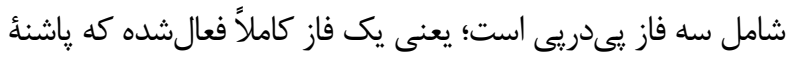

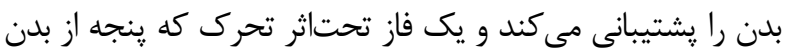

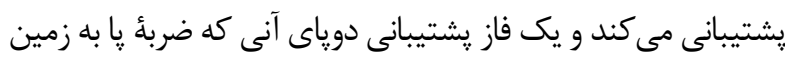

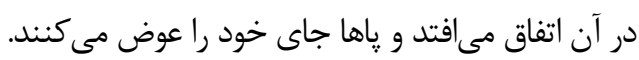

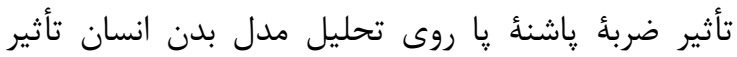
بسزايى مى كذارد. برايناساس در مطالعه ديخرى براى تحاس تحليل ديناميك راهرفتن يايدار روى زمين، مدل هفتلينكى غين غيرفعال

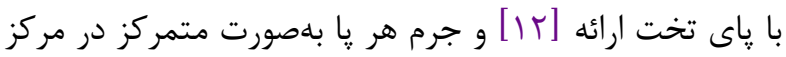


راهرفتن خندين بخش را شامل مىشوند. هر جرخئ كامل راهرفتن

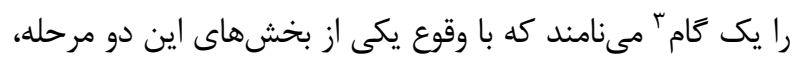

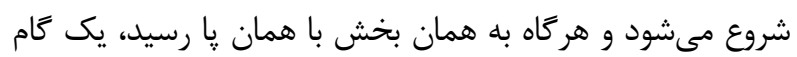

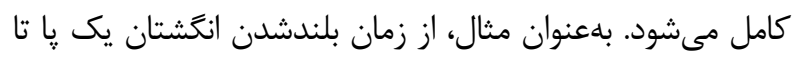

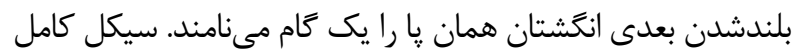

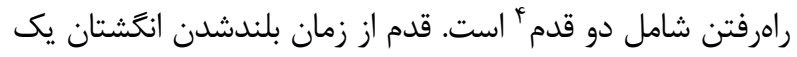

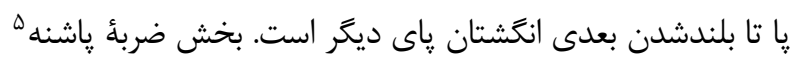
(H.S)

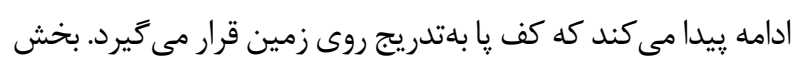

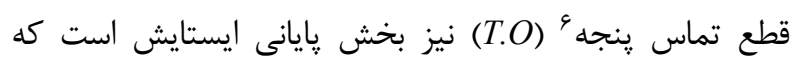

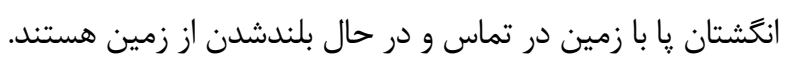

\section{مدل ديناميكى شخص در مرحلة شناورى هنعام عمليات}

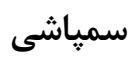

شكل 1 مدل ديناميكى درنظركرفتهشده براى شخص در

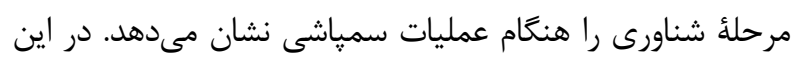

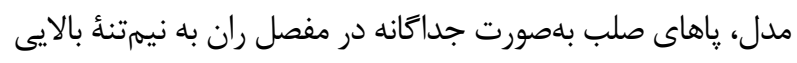

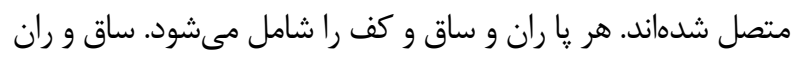

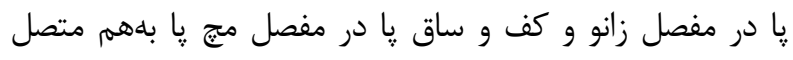

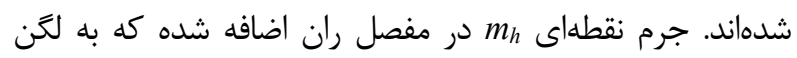

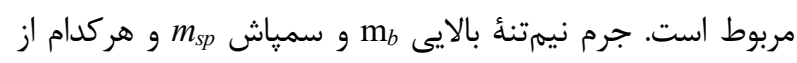

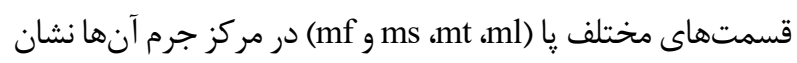
داده شده است. مركز جرم سمياش درمقايسهبا مركز جرم نيمتئن

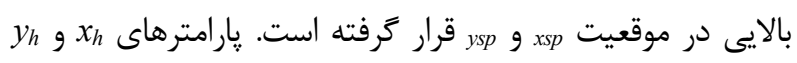

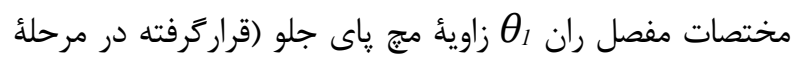
ايستايش)،

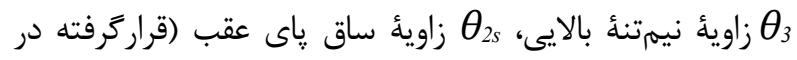
مرحلة شناورى) و و شناورى) است.

جهت مثبت براى همهٔ زوايا، پادساعتخرد در نظر كرفته مىشود.

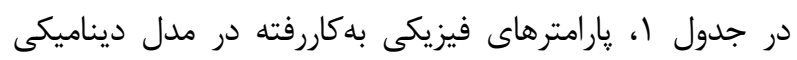
ارائهشده، بههمراه مقادير عددى آنها داده شده بده است

${ }^{4}$ Step

${ }^{5}$ Heel Strike

${ }^{6}$ Toe Off
هنخام مدولاسيون سرعت، غالباً زاوئُ اندامهاى عقبى را بيش از كشتاور مج يا تعديل مى منند.

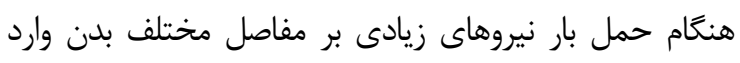

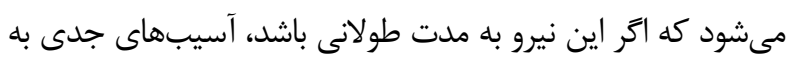

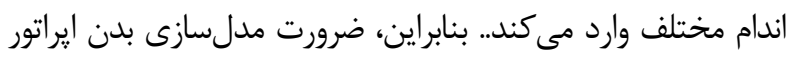

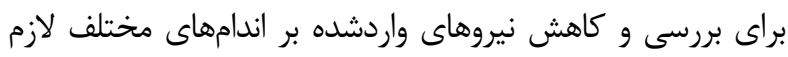

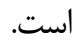

تاكنون، مطالعهاى روى مدل ديناميكى شخص براى بررسى

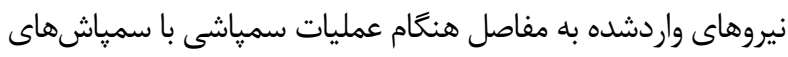

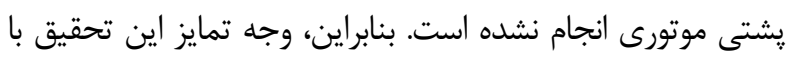

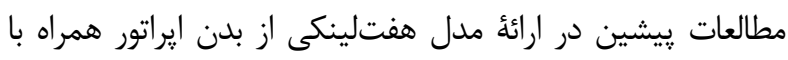

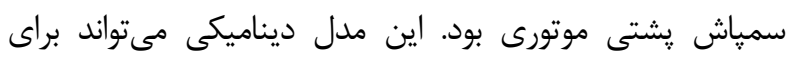

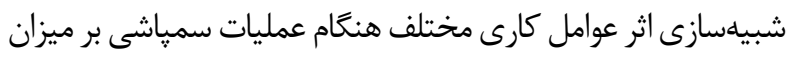

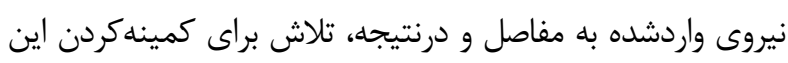

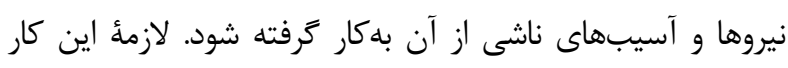

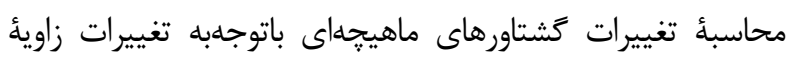

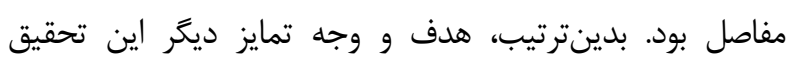

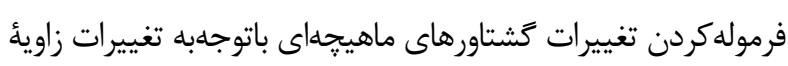

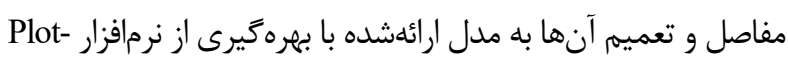
digitizer

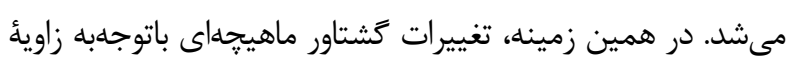

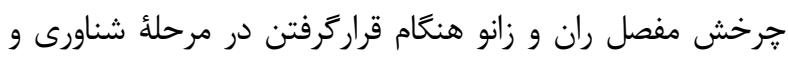

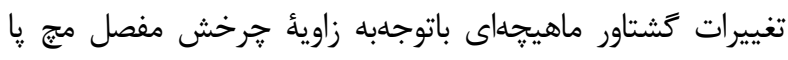

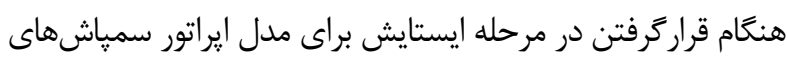

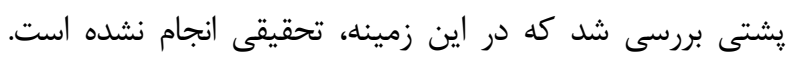

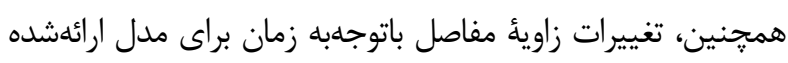
برآورد شد. روش كار راهرفتن شامل خرخهاى از فعاليتهاست كه براى هر اندام

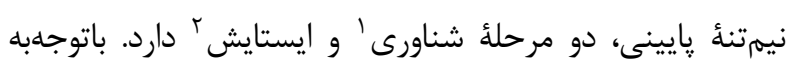

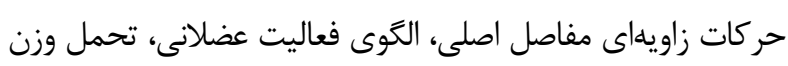

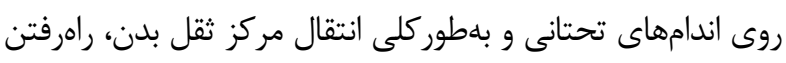

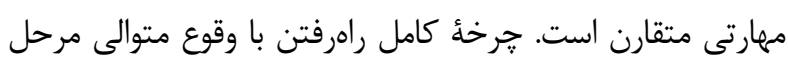

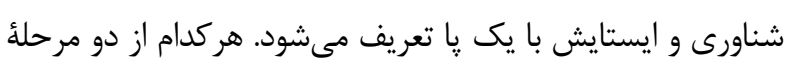



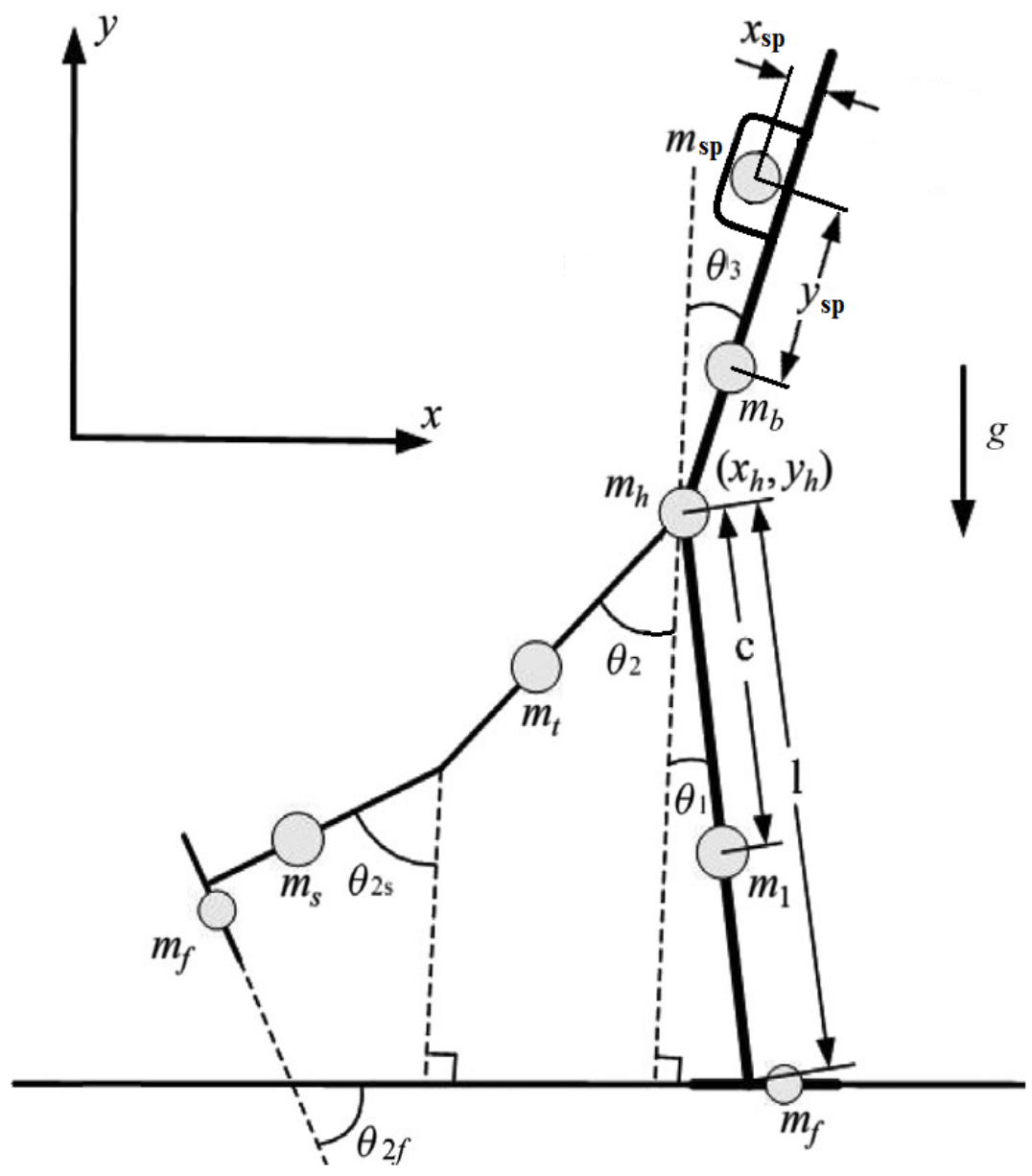

شكل ا. مدل ديناميكى ارائهده براى شخص در مرحلة شناورى هنعًام عمليات سمياشى رِ

جدول ا. مقادير يارامترهاى مدل ديناميكى ارائهشده براى شخص در مرحلة شناورى هنگًام عمليات سمياشى

\begin{tabular}{|c|c|c|c|}
\hline مقدار & 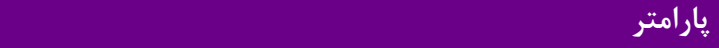 & ن & رديف \\
\hline V • متر & طول یا & $l$ & 1 \\
\hline اس/ן • متر & طول ساق یا & $l_{s}$ & $r$ \\
\hline ^ץ/ן • متر & طول ران & $l_{t}$ & r \\
\hline r|\& & جرم نيمتنـة بالايى & $m_{b}$ & f \\
\hline 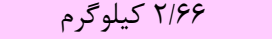 & جرم كف يا & $m_{f}$ & $\Delta$ \\
\hline 19/9V & جرم لَن & $m_{h}$ & 9 \\
\hline ساه/11 كيلوگرم & جرم یا & $m_{l}$ & $V$ \\
\hline 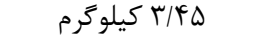 & جرم ساق گا & $m_{s}$ & $\Lambda$ \\
\hline |ه| • ا كيلوگرم & جرم سمياش & $m_{s p}$ & 9 \\
\hline N/FV كيلو & جرم ران & $m_{t}$ & 1. \\
\hline 9/1 1 متر بر مجذور ثانيه & شتاب گرانش & $g$ & 11 \\
\hline | l V • متر & مختصات افقى مركز جرم سمياش باتوجلبه مركز جرم نيمتنـٔ بالايى & $x_{s p}$ & it \\
\hline 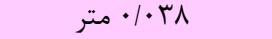 & مختصات قائم مركز جرم سمياش باتوجابه مركز جرم نيمتنهُ بالايى & $y_{s p}$ & Ir \\
\hline
\end{tabular}


وضعيت شخص هنكام ايستادن ثبت و بهعنوان مرجعى براى

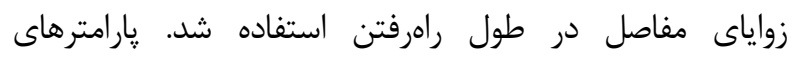

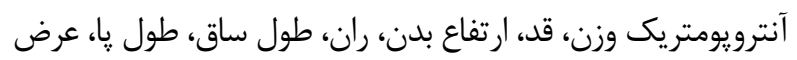

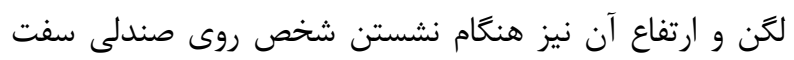

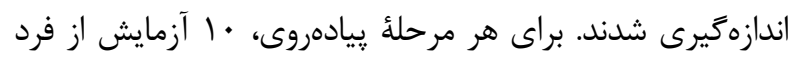

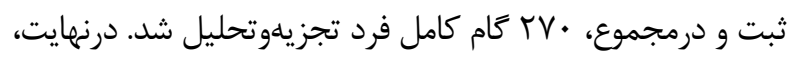

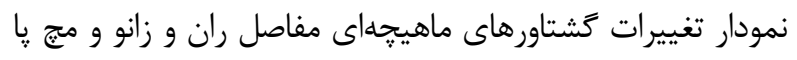

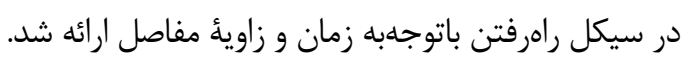

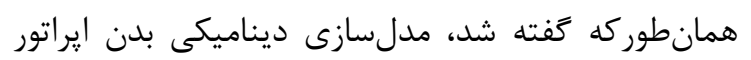

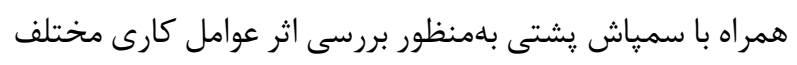
روى نيروى مفاصل، مستلزمِ داشتن فرم صريح معادلات گَشتاور

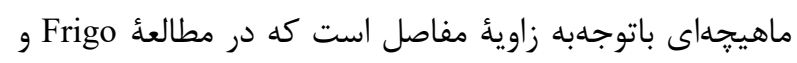

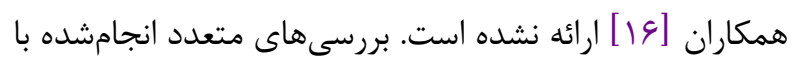

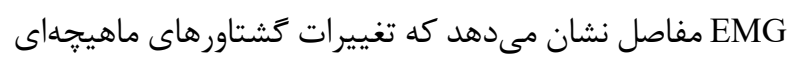

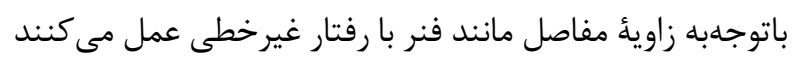

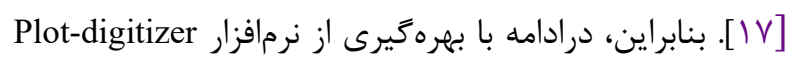

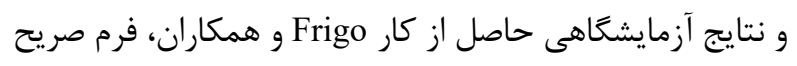

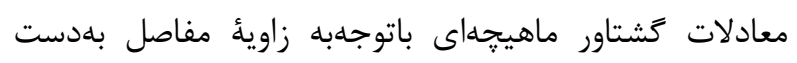

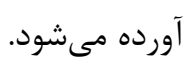

استخراج اطلاعات از نمودارها يكى از اقداماتى است كه در

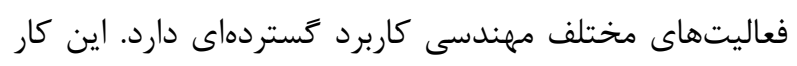

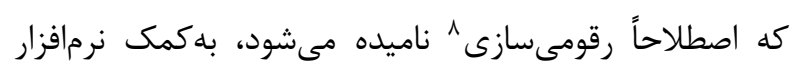
Plot-digitizer محورها كاليبره شوند. كاليبرهكردن با انتخاب سه نقطة دائ دلخواه روى نمودار انجام مىشود. اين سه نقطه بايد مختصاتى معلوم داشته باشند و روى يك خط نباشند و تاحدممكن از هم فم فاصلئ

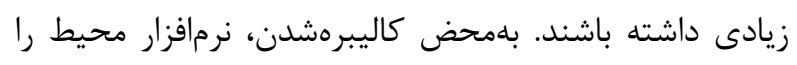

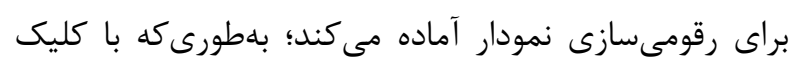

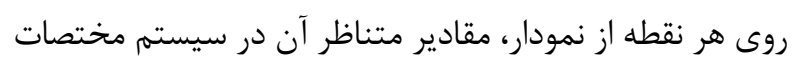

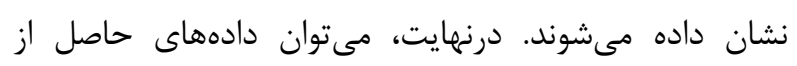

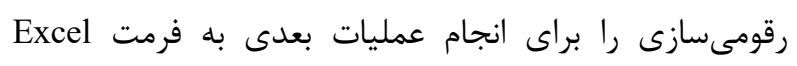

$$
\text { ذخيرهسازى كرد. }
$$

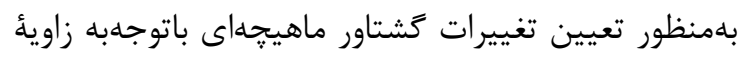

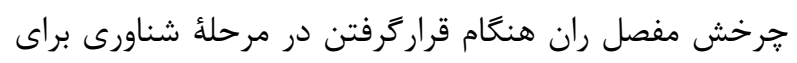

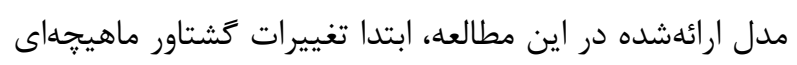

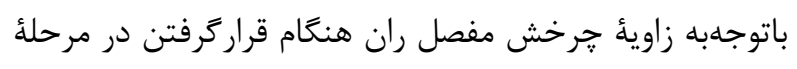

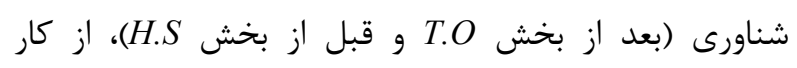

\section{كشتاور هاى ماهيجهاى}

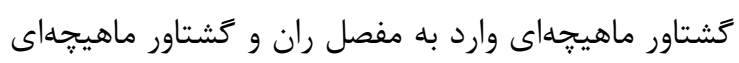

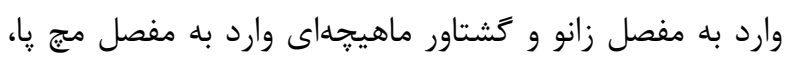

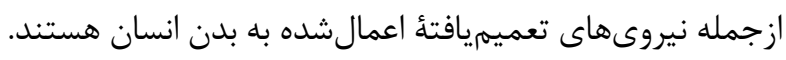

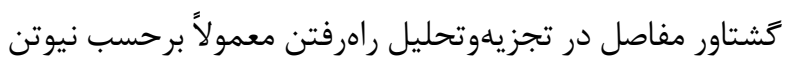

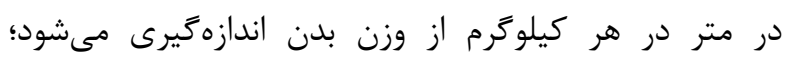

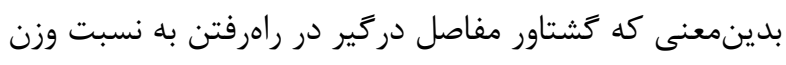

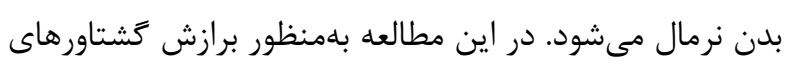

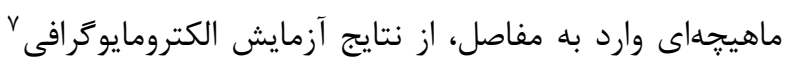

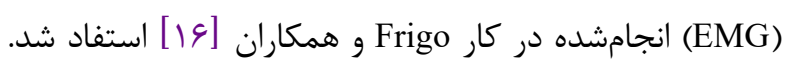

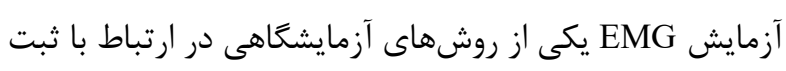

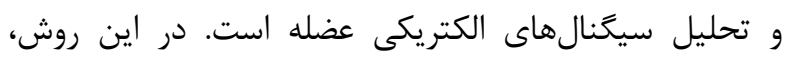

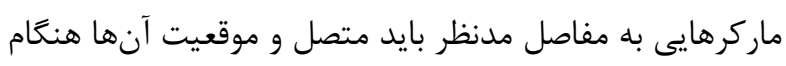

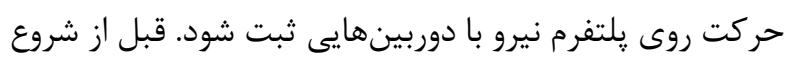

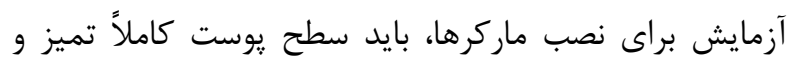

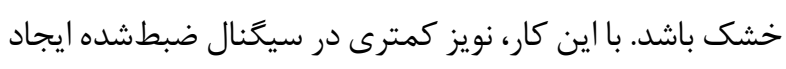

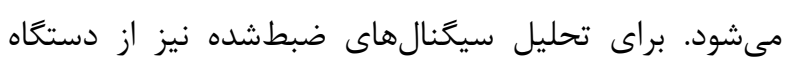

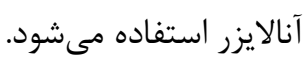

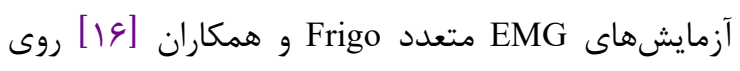

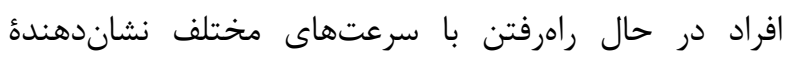

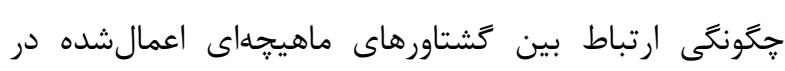

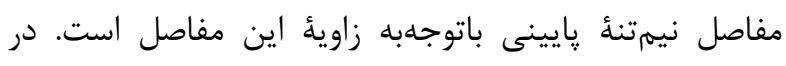

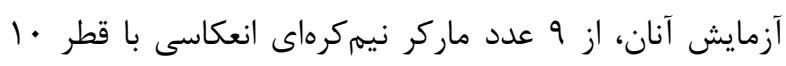

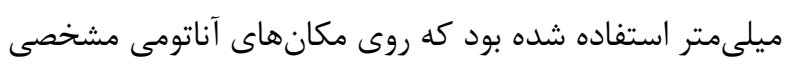

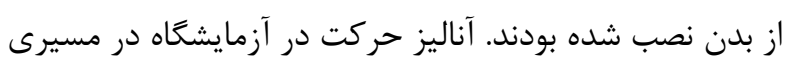

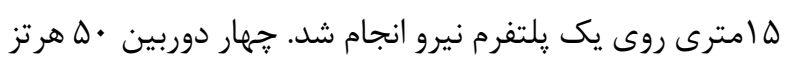

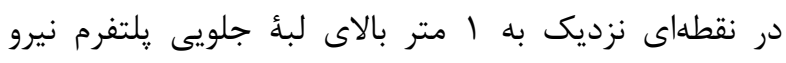

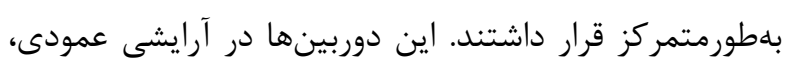

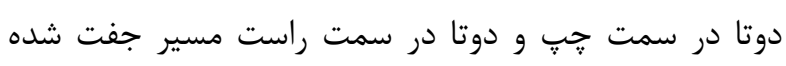

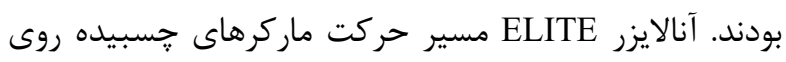
يوست فرد را تحليل مى كرد.

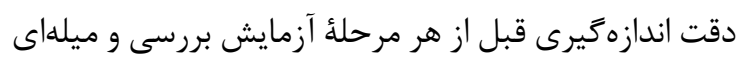

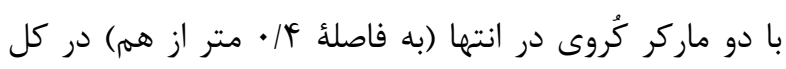

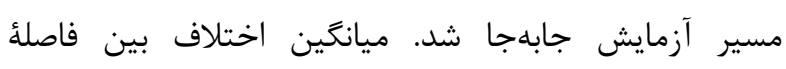

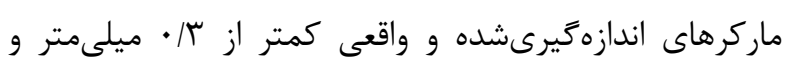

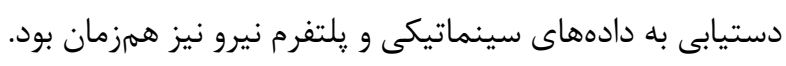

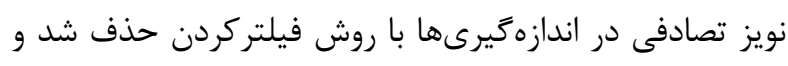


صفر تا ها درجه، اندازء كَشتاور بلطورملايم كاهش و در بخش

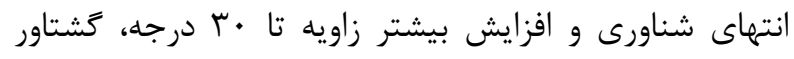

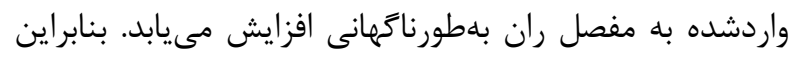

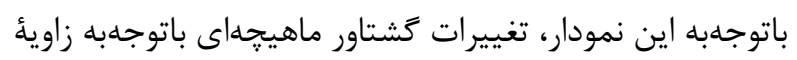

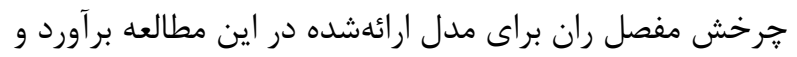

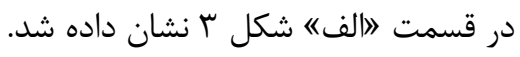

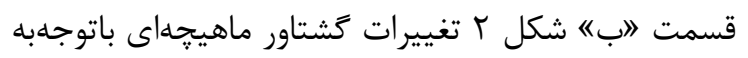
زاوية جرخش مفصل زانو را هنكام قراركرفتن در مرحلئ شناورى

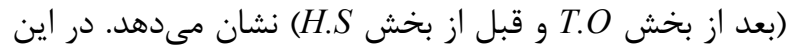

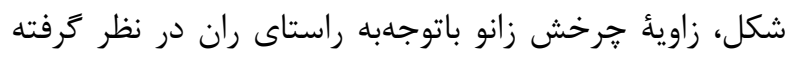

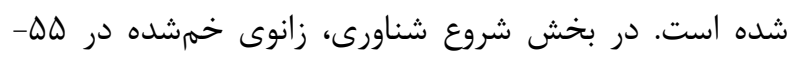

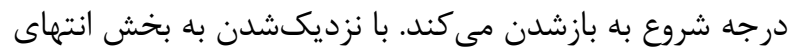

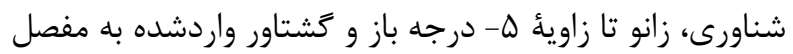

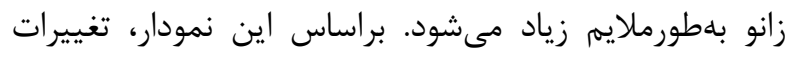

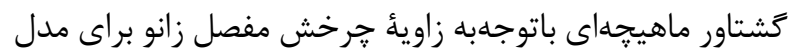

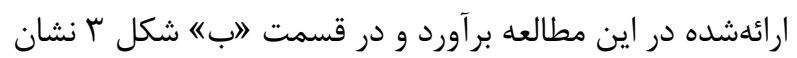
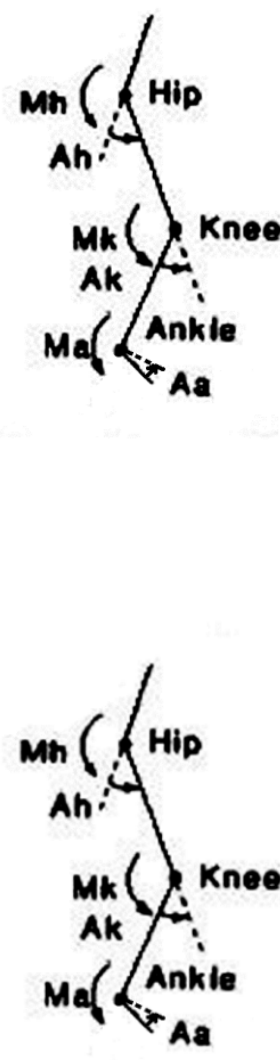

آزمايشكاهي Frigo و همكاران [1 ] انتخاب شد. سيس با كمى نرمافزار Plot-digitizer، تعدادى از نقاط نمودار مدنظر تعيين

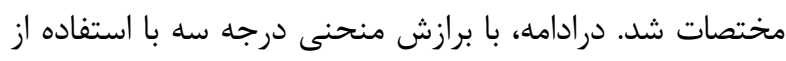

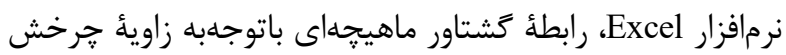

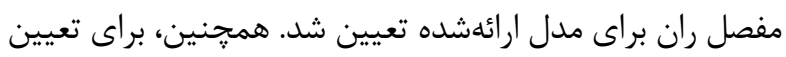
كشتاور ماهيجهاى باتوجهبه زاوئ جرخش مفصل زان زانو در مرحلئ شناورى (بعد از بخش T.O و قبل از بخش

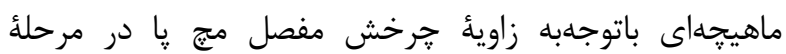

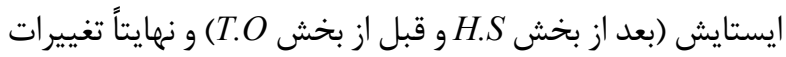
زاويه مفاصل باتوجهبه زمان نيز مانند مرحلة قبل بحل عمل شد.

بافته ها

قسمت 》الف) شكل r تغييرات گشتاور ماهيجهاى باتوجهبه زاوئه جرخش مفصل ران را هنكام قرار كَفتن در مرحلة شناورى

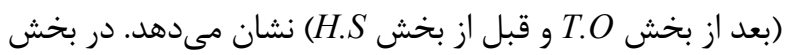

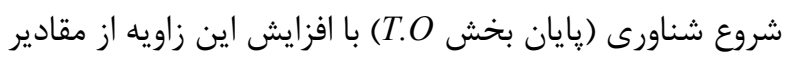

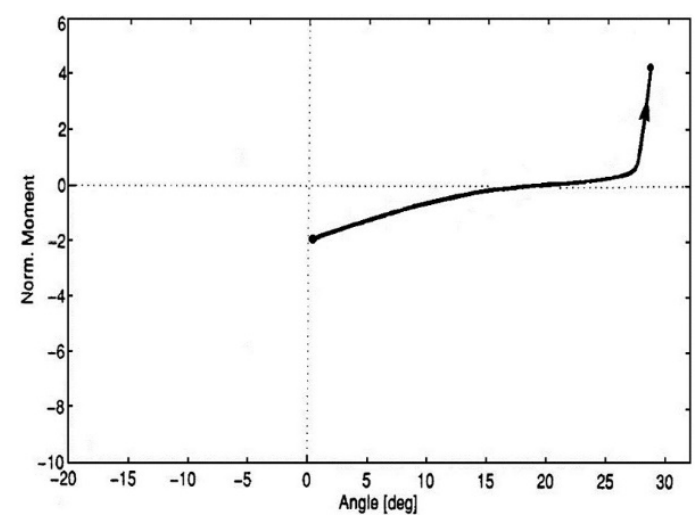

(الف)

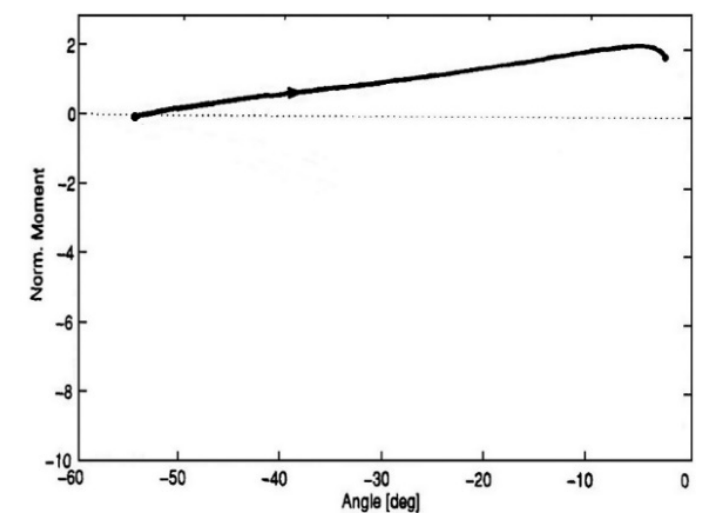

(ب) 

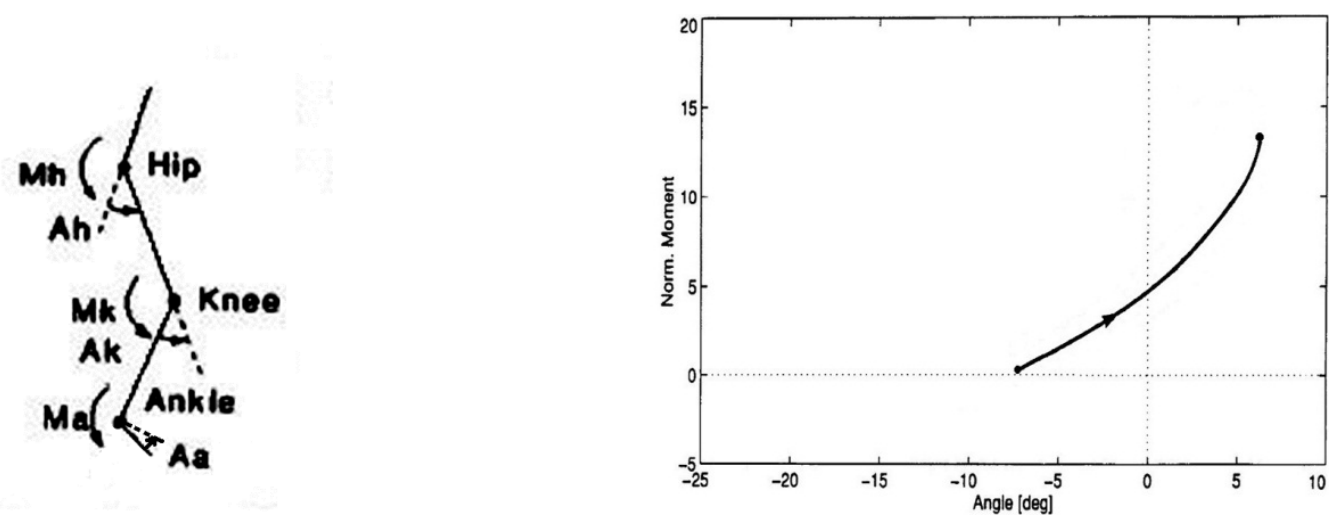

(ج)

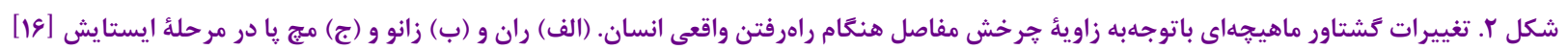

مقدار گشتاور واردشده به مفصل مج يا افزايش مىيابد. براساس اين

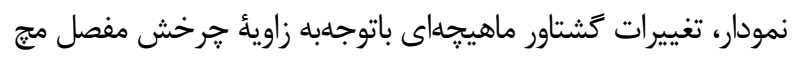

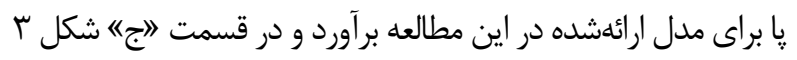
نشان داده شد.
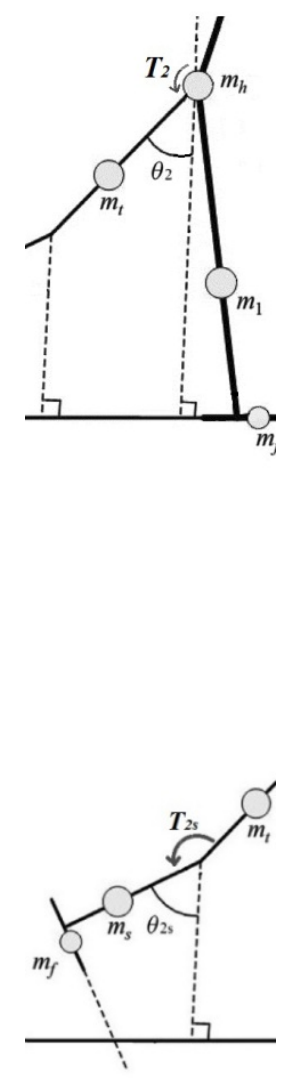

در قسمت "ج" شكل r، تغييرات گشتاور ماهيجهاى باتوجهبه

زاويةٔ جرخش مفصل مجز يا هنگام قراركرفتن در مرحلة ايستايش (بعد از بخش H.S و قبل از بخش T.O م. نشان داده شده است. همان طوركه

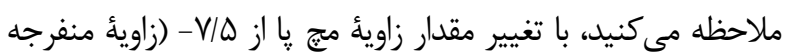

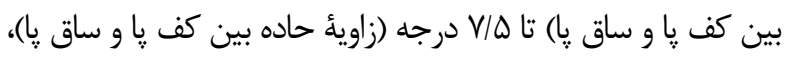

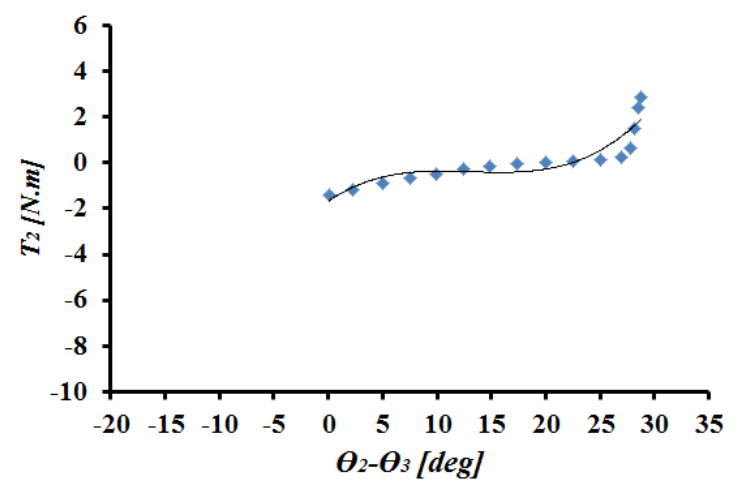

(الف)

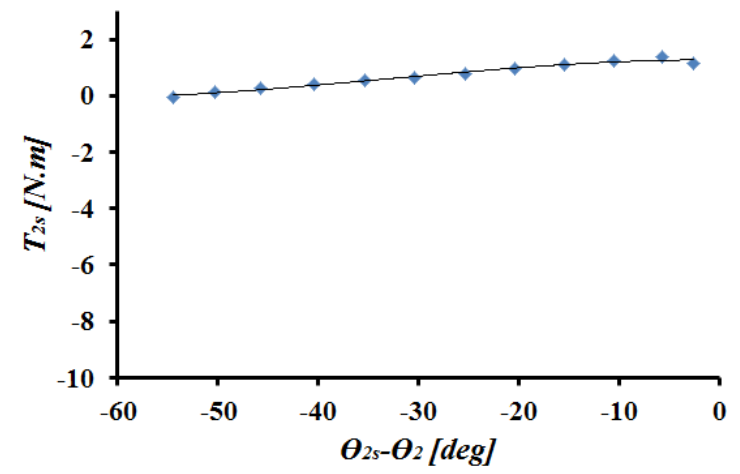

(ب) 

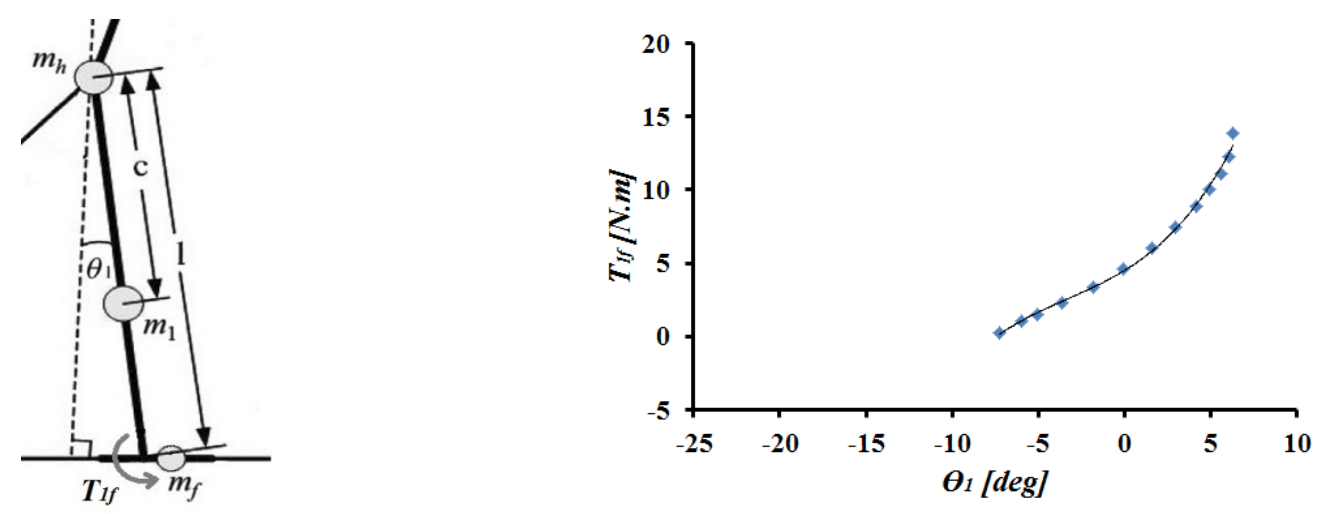

(ج)

شكل r. تغييرات كشتاور ماهيجهاى باتوجدبه زاوية حرخش مفاصل در مدل ارائهشده. (الف) ران در مرحلئ شناورى و (ب) زانو در مرحلئ شناورى و (ج) متج يا در مرحلة ايستايش

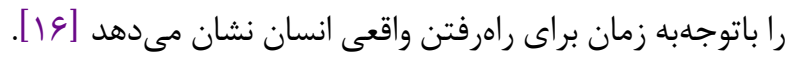
بررسىهاى متعدد انجامشده با EMG مفاصل ران و زانو و

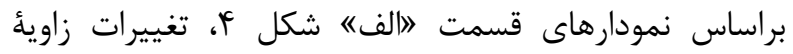

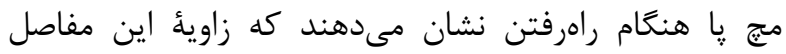

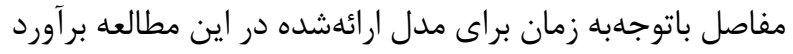

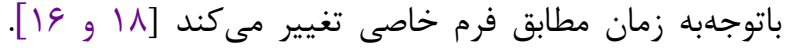

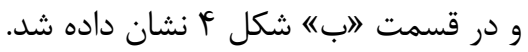

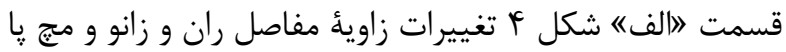

Angle [deg]
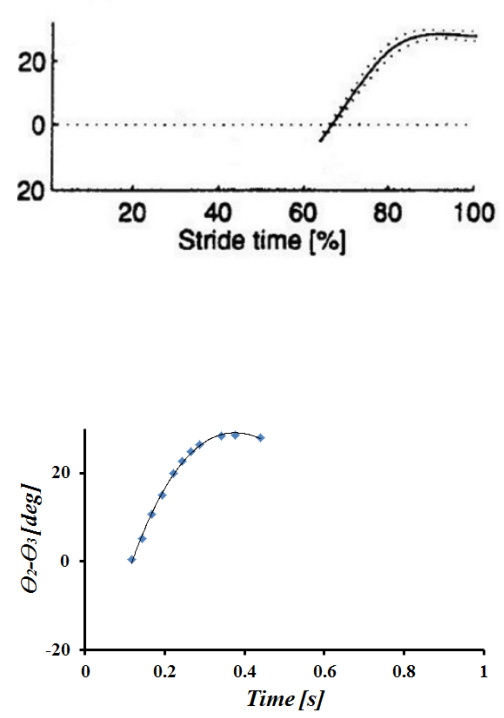

(ران)

\section{Angle [deg]}

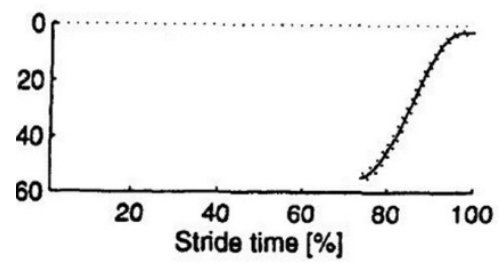

(الف)

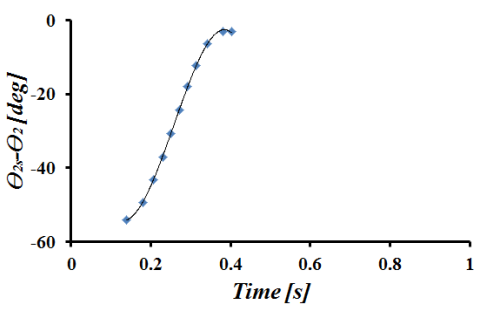

(زانو)
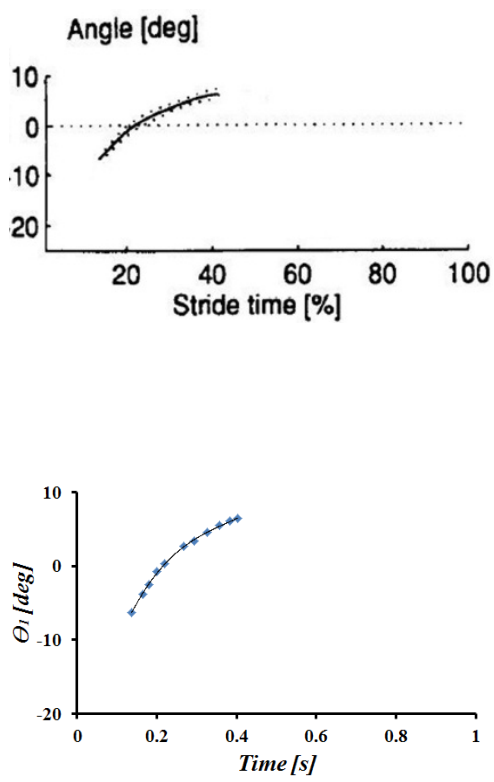

(مج پيا)

(ب)

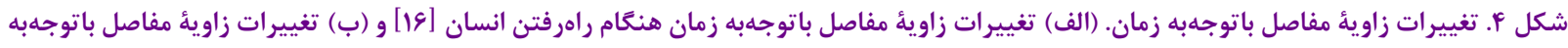
زمان براى مدل ارائهشده

منحنى درجه سه به منحنىهاى بdدستآمده، معادلات مرتبط تعيين و در جدول r ارائه شدهاند. يارامتر

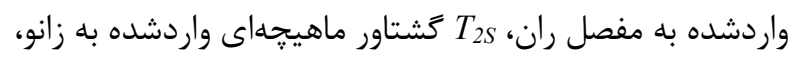

در قسمتهاى قبل، تغييرات گشتاور ماهيجهاى باتوجهبه زاوئُ جرخش مفصل ران و زانو و مج ريا و تغييرات زاوئُ اين

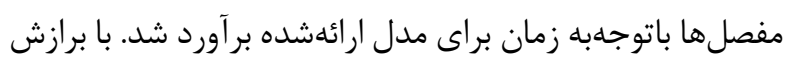




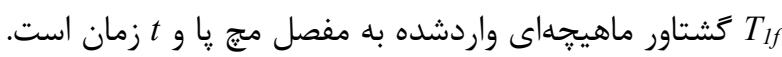
ديخر يارامترهاى بهكاررفته در اين رابطهها در قسمت معرفى بانى

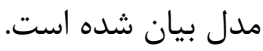

جدول r. معادلات بهدست آمده از تغييرات گشتاورهاى ماهيجهاى وتغييرات زاويه مفصل هاى ران و زانو و مجج پِا

\begin{tabular}{|c|c|}
\hline 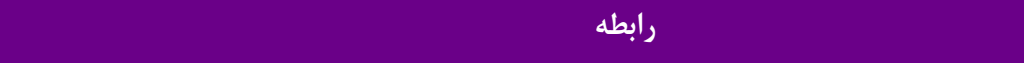 & شماره رابطه \\
\hline$T_{2}=0.0007\left(\theta_{2}-\theta_{3}\right)^{3}-0.0258\left(\theta_{2}-\theta_{3}\right)^{2}+0.3236\left(\theta_{2}-\theta_{3}\right)-1.6792$ & 1 \\
\hline$T_{2 s}=-0.0011\left(\theta_{2 s}-\theta_{2}\right)^{2}-0.0029\left(\theta_{2 s}-\theta_{2}\right)+1.2683$ & $r$ \\
\hline$T_{1 f}=0.0043 \theta_{1}^{3}+0.0429 \theta_{1}^{2}+0.5052 \theta_{1}+3.1455$ & $r$ \\
\hline$\theta_{2}-\theta_{3}=373.64 t^{3}-762.66 t^{2}+414.86 t-38.89$ & r \\
\hline$\theta_{2 s}-\theta_{2}=-6357.5 t^{3}+4911.3 t^{2}-958.48 t+1.24$ & $\Delta$ \\
\hline$\theta_{1}=451.84 t^{3}-513.31 t^{2}+218.5 t-27.77$ & \& \\
\hline
\end{tabular}

اين وابستخى ناشى از عوامل عصبى و خواص فيزيولوزيكى

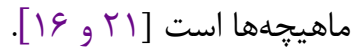

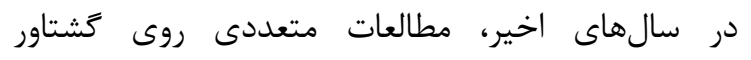

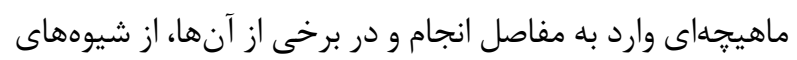

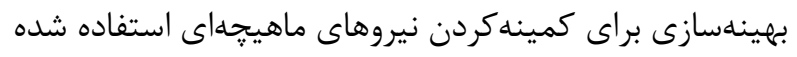

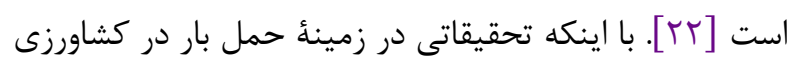

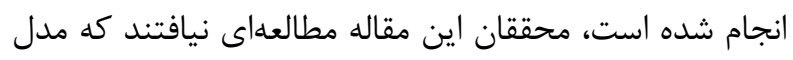

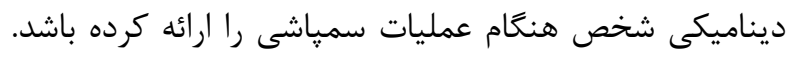

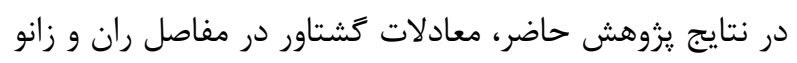

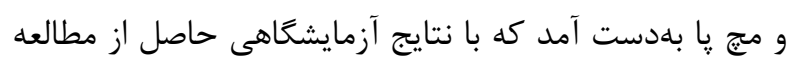
Frigo

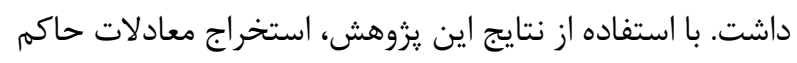

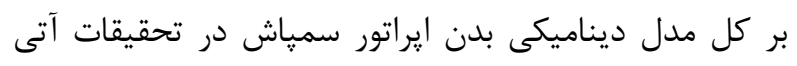

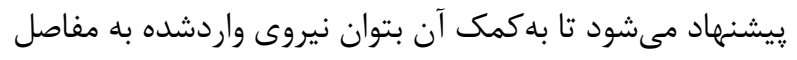
را تحتاثر يارامترهاى كارى مختلف شبيهسازى و مقادير كمينه

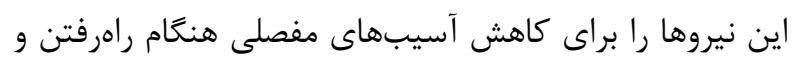
حمل سمياش يشتى موتورى تعيين كرد.

$$
\text { نتيجه كيرى }
$$

دردهاى مفصلى در بين كشاورزان بسيار شايع است. با وجود آسيبهاى مفصلى، بسيارى از كاركنان اين بخش خفار خانهنشين
كشاورزى يكى از فعاليتهاى شغلى گسترده و ريسكيذير

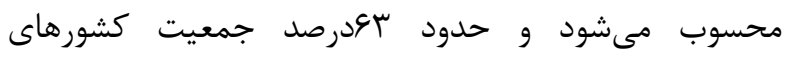

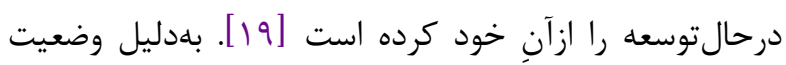

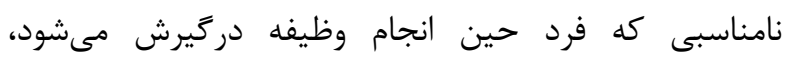

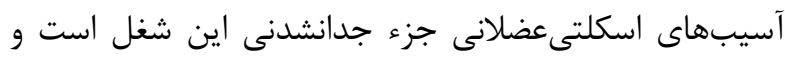

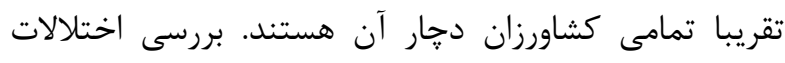

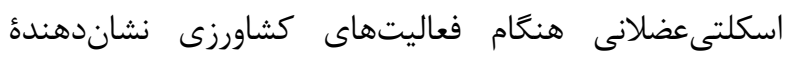

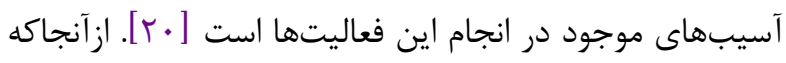

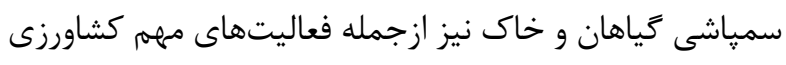

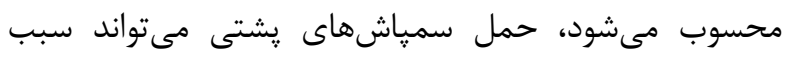

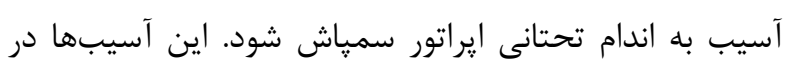

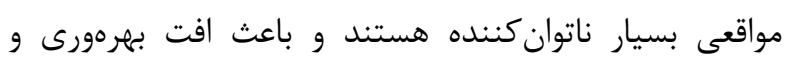

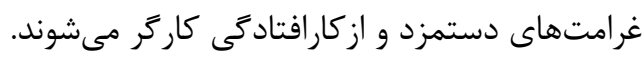

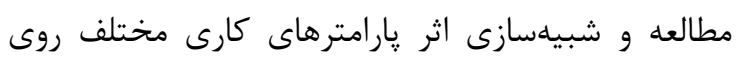

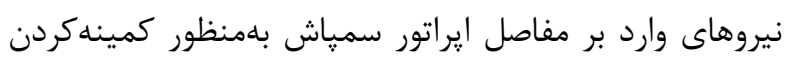

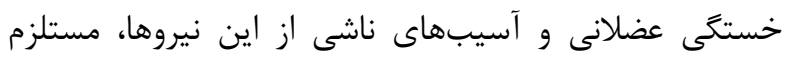

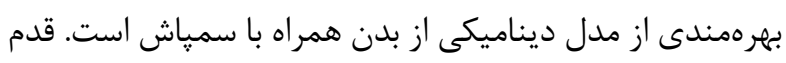

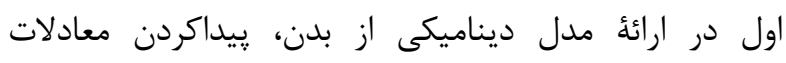

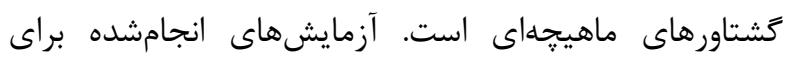

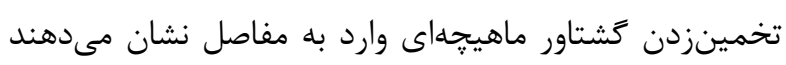
كه كَتاور مفاصل فقط به تغييرات زاوية مفاصل وابسته هستند.

${ }^{9}$ Sinkjaer 


\section{تقدير و تشكر}

نويسند

خدماتى دانشخاه شهركرد براى انجام اين بزوهش تشكر و و قدردانى مى كنند.

$$
\text { تعارض منافع }
$$

بين نويسندگان اين مقاله هيجَّنه تعارضى در منافع وجود ندارد. منابع مالى

منابع مالى اين مطالعه توسط نويسندكان تامين شده است.

\section{References}

1. Ju MS, Mansour JM. Simulation of the double limb support phase of human gait. J Biomech Eng. 1988 ؛

\section{0)3 : 223-229. [DOI:10.1115/1.3108435]} [PMID]

2. Anbarian M, Rajabian F, Ghasemi MH, Heidari Moghaddam R. The effect of the heel wedges on the electromyography activities of the selected lower back muscles during load lifting. Iran J Ergon. 2018; 5(3):14-21. [DOI:10.30699/jergon.5.3.12]

3. Azhdardor M, Tabatabaei Sh. Relationship between musculoskeletal disorders and quality of life in employees of selected hospitals in Golestan province. Iran J Ergon. 2019; 6(4):31-36. [DOI:10.30699/jergon.6.4.30]

4. Ataei SS, Heydari P, Varmazyar S. Investigation of correlation of musculoskeletal disorders with work ability index and allowable load lifting limit. Iran J Ergon. 2017; 4(4):15-22. [DOI:10.21859/joe$\underline{04043]}$

5. Cholewicki J, McGill SM. EMG assisted optimization: a hybrid approach for estimating muscle forces in an indeterminate biomechanical model. J Biomech. 1994; 27(10): 1287-1289. [DOI:10.1016/0021-9290(94)90282-8]

6. Alexander RM. Simple models of human movement. 1995; 48: 461-470. [DOI:10.1115/1.3005107]

7. Kuo AD. A simple model of bipedal walking predicts the preferred speed-step length relationship. J Biomech Eng. 2001; 123(3): 264269. [DOI:10.1115/1.1372322] [PMID]

8. Borzova E, Hurmuzlu Y. Passively walking fivelink robot. Automatica. 2004: 40(4): 621-629. [DOI:10.1016/j.automatica.2003.10.015]

9. Vimieiro C, Andrada E, Witte H, Pinotti M. A computational model for dynamic analysis of the
شدهاند يا بهدليل سنخينى كارها تغيير شغل داده و از كشاورزى فاصله گرفتهاند. سمياشى گَياهان و خاكى با سمياش يشتى نيروى زيادى به بدن كشاورزان در اين بخش وارد مىكند.

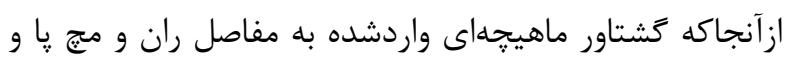
زانو، ازجمله نيروهاى تعميميافتهُ مدل ديناميكى بدن محسوب

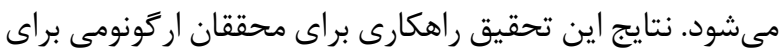
استخراج معادلات حاكم بر كل مدل ديناميكى بدن ايراتور

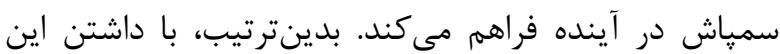
معادلات و شبيهسازى اثر يارامترهاى كارى مختلف بر ميزان نيروى واردشده به مفاصل و تلاش براى كمينهكردن اين نيروها، مىتوان از آسيبهاى مفصلى هنگام راهرفتن و حمل سمياش يشتى موتورى جلوگيرى و مقادير استاندارد را تعيين كرد.

human gait. Comput Methods Biomech Biomed Eng. $\quad 2015 ; \quad$ 18(7): 799-804. [DOI:10.1080/10255842.2013.848859] [PMID]

10. Tlalolini D, Chevallereau C, Aoustin Y. Humanlike walking: Optimal motion of a bipedal robot with toe-rotation motion. IEEE-ASME Trans Mech. 2010; 16(2): 310-320. [DOI:10.1109/TMECH.2010.2042458]

11. Liu Y, Zang X, Heng S, Lin Z, Zhao J. Human-Like Walking with Heel Off and Toe Support for Biped Robot. Appl Sci. 2017; 7(6): 499. [DOI:10.3390/app7050499]

12. Huang Y, Wang L, Chen B, Wang Q, Xie G. Modeling and gait selection of passivity-based seven-link bipeds with dynamic series of walking phases. Robotica. 2012; 30(1): 39-51. [DOI:10.1017/S0263574711000397]

13. Hume DR, Navacchia A, Ali AA, Shelburne KB. The interaction of muscle moment arm, knee laxity, and torque in a multi-scale musculoskeletal model of the lower limb. J Biomech. 2018; 76: 173-180. [DOI:10.1016/j.jbiomech.2018.05.030] [PMID]

14. Winter DA, Robertson DGE. Joit torque and energy patterns in normal gait. Biol Cybern. 1978; 29(3): 137-142. [DOI:10.1007/BF00337349] [PMID]

15. Hsiao H, Knarr BA, Higginson JS, Binder-Macleod SA. The relative contribution of ankle moment and trailing limb angle to propulsive force during gait. Hum Mov Sci. 2015; 39: 212-221. [DOI:10.1016/j.humov.2014.11.008] [PMID] [PMCID]

16. Frigo C, Crenna P, Jensen LM. Moment-angle relationship at lower limb joints during human walking at different velocities. J Electromyogr Kinesiol. 1996; 6(3): 177-190. [DOI:10.1016/10506411(96)00030-2] 
17. Weiss PL, Kearney RE, Hunter IW. Position dependence of ankle joint dynamics-I. Passive mechanics. J Biomech. 1986; 19(9): 727-735. [DOI:10.1016/0021-9290(86)90196-X]

18. Agrawal SK, Banala SK, Fattah A, Sangwan V, Krishnamoorthy V, Scholz JP, et al. Assessment of motion of a swing leg and gait rehabilitation with a gravity balancing exoskeleton. IEEE Trans Neural Syst Rehabil Eng. 2007; 15(3):410-420. [DOI:10.1109/TNSRE.2007.903930] [PMID]

19. Levy B, Wegman D. Occupational health recognizing and preventing work-related disease and injury. 4th Ed. Philadelphia: Lippincott Williams \& Wilkins; 2000: 729.

20. Houshyar E, Kim IJ. Understanding musculoskeletal disorders among Iranian apple harvesting. Int $\mathrm{J}$ Ind Ergon. 2018; 67: 32-40. [DOI:10.1016/i.ergon.2018.04.007]

21. Sinkjaer T, Toft E, Andreassen S, Hornemann BC. Muscle stiffness in human ankle dorsiflexors: intrinsic and reflex components. J Neurophysiol. 1988; 60(3)

1110-1121. [DOI:10.1152/jn.1988.60.3.1110] [PMID]

22. Pedotti A, Krishnan VV, Stark L. Optimization of muscle-force sequencing in human locomotion. Math Biosci. 1978; 38(1-2): 57-76. [DOI:10.1016/0025-5564(78)90018-4] 